\title{
Wnt inhibitory factor 1 (WIF1) is a marker of osteoblastic differentiation stage and is not silenced by DNA methylation in osteosarcoma
}

Baker, Emma K ; Taylor, Scott ; Gupte, Ankita ; Chalk, Alistair M ; Bhattacharya, Shreya ; Green, Alanna C ; Martin, T John ; Strbenac, Dario ; Robinson, Mark D ; Purton, Louise E ; Walkley, Carl R

\begin{abstract}
Wnt pathway targeting is of high clinical interest for treating bone loss disorders such as osteoporosis. These therapies inhibit the action of negative regulators of osteoblastic Wnt signaling. The report that Wnt inhibitory factor 1 (WIF1) was epigenetically silenced via promoter DNA methylation in osteosarcoma (OS) raised potential concerns for such treatment approaches. Here we confirm that Wif1 expression is frequently reduced in OS. However, we demonstrate that silencing is not driven by DNA methylation. Treatment of mouse and human OS cells showed that Wif1 expression was robustly induced by HDAC inhibition but not by methylation inhibition. Consistent with HDAC dependent silencing, the Wif1 locus in OS was characterized by low acetylation levels and a bivalent H3K4/H3K27-trimethylation state. Wif1 expression marked late stages of normal osteoblast maturation and stratified OS tumors based on differentiation stage across species. Culture of OS cells under differentiation inductive conditions increased expression of Wif1. Together these results demonstrate that Wif1 is not targeted for silencing by DNA methylation in OS. Instead, the reduced expression of Wif1 in OS cells is in context with their stage in differentiation.
\end{abstract}

DOI: https://doi.org/10.1016/j.bone.2014.12.063

Posted at the Zurich Open Repository and Archive, University of Zurich

ZORA URL: https://doi.org/10.5167/uzh-114976

Journal Article

Accepted Version

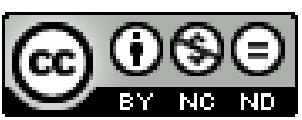

The following work is licensed under a Creative Commons: Attribution-NonCommercial-NoDerivatives 4.0 International (CC BY-NC-ND 4.0) License.

Originally published at:

Baker, Emma K; Taylor, Scott; Gupte, Ankita; Chalk, Alistair M; Bhattacharya, Shreya; Green, Alanna C; Martin, T John; Strbenac, Dario; Robinson, Mark D; Purton, Louise E; Walkley, Carl R (2015). Wnt inhibitory factor 1 (WIF1) is a marker of osteoblastic differentiation stage and is not silenced by DNA methylation in osteosarcoma. Bone, 73:223-232.

DOI: https://doi.org/10.1016/j.bone.2014.12.063 
Wnt inhibitory factor 1 (WIF1) is a marker of osteoblastic differentiation stage and is not silenced by DNA methylation in osteosarcoma.

Emma K Baker ${ }^{1,2^{*}}$, Scott Taylor $^{1}$, Ankita Gupte $^{1}$, Alistair M Chalk ${ }^{1,2}$, Shreya Bhattacharya $^{1,2}$, Alanna C Green ${ }^{1,2}$, T John Martin ${ }^{2,3}$, Dario Strbenac ${ }^{4}$, Mark D Robinson ${ }^{5,6}$, Louise E Purton ${ }^{1,2}$ \& Carl R Walkley ${ }^{1,2^{*}}$.

${ }^{1}$ Stem Cell Regulation Unit, St. Vincent's Institute of Medical Research, Fitzroy, Australia;

${ }^{2}$ Department of Medicine, St. Vincent's Hospital, University of Melbourne, Fitzroy, Australia;

${ }^{3}$ Bone Cell Biology and Disease Unit, St. Vincent's Institute of Medical Research, Fitzroy, Australia;

${ }^{4}$ Cancer Epigenetics, Garvan Institute of Medical Research, Darlinghurst, Australia.

${ }^{5}$ Institute of Molecular Life Sciences, University of Zurich, Zurich, Switzerland;

${ }^{6}$ SIB Swiss Institute of Bioinformatics, University of Zurich, Zurich, Switzerland.

${ }^{*}$ Correspondence should be addressed to:

Emma Baker and Carl Walkley

St Vincent's Institute

T: 61392882480

F: 61394162676

Email:

ebaker@svi.edu.au

cwalkley@svi.edu.au

Running Title: Regulation of WIF1 in osteosarcoma 


\begin{abstract}
Wnt pathway targeting is of high clinical interest for treating bone loss disorders such as osteoporosis. These therapies inhibit the action of negative regulators of osteoblastic Wnt signaling. The report that Wnt inhibitory factor 1 (WIF1) was epigenetically silenced via promoter DNA methylation in osteosarcoma (OS) raised potential concerns for such treatment approaches. Here we confirm that Wif1 expression is frequently reduced in OS. However, we demonstrate that silencing is not driven by DNA methylation. Treatment of mouse and human OS cells showed that Wif1 expression was robustly induced by HDAC inhibition but not by methylation inhibition. Consistent with HDAC dependent silencing, the Wif1 locus in OS was characterized by low acetylation levels and a bivalent $\mathrm{H} 3 \mathrm{~K} 4 / \mathrm{H} 3 \mathrm{~K} 27$-trimethylation state. Wif1 expression marked late stages of normal osteoblast maturation and stratified OS tumors based on differentiation stage across species. Culture of OS cells under differentiation inductive conditions increased expression of Wif1. Together these results demonstrate that Wif1 is not targeted for silencing by DNA methylation in OS. Instead, the reduced expression of Wif1 in OS cells is in context with their stage in differentiation.
\end{abstract}

Keywords: Osteosarcoma, WIF1, HDAC, methylation, osteoblast, osteoporosis 


\section{Introduction}

Osteosarcoma (OS) is the most common primary tumor of bone, and fifth most common malignancy in children. Through the use of intensive chemotherapy and improvements in surgical resection, the 5-year survival rate for patients with localized disease has reached $70 \%$ [1]. However, survival rates have failed to substantively improve over the past three decades and patients continue to be at high risk of therapy-related complications, most notably cardiac toxicity and deafness induced by the chemotherapeutic regimes [2]. Metastatic dissemination is also frequent in patients; almost $20 \%$ of patients present at diagnosis with metastatic disease and almost all patients with recurrent disease will develop metastatic lesions [3]. Despite progress in our knowledge of OS biology and genetics, 5 year survival rates remain at $\sim 30 \%$ for patients with metastatic disease [1]. New treatment strategies are needed to improve long-term patient survival and improve their post-treatment quality of life.

OS originates from a disruption in the osteoblastic lineage differentiation process. Histologically, OS tumors can resemble different stages of osteoblast maturation. Conventional OS, the most common diagnosis, can present as one of three subtypes; osteoblastic $(\sim 60 \%)$, fibroblastic $(\sim 10 \%)$ and chondroblastic $(\sim 10 \%)$ [4]. Normal cell lineage commitment is intricately linked with epigenetic processes, and gene specific epigenetic signatures and chromatin landscapes can define stages of development [5-7]. Understanding the epigenetic landscapes of normal cell counterparts will play a role in deciphering the epigenomes of cancer cells.

The mechanisms that underlie the disrupted differentiation process in OS are still being elucidated. OS tumors are characterized by multiple somatic chromosomal lesions, including localized regions with high levels of mutations (kataegis) and chromosomal rearrangements (chromothripsis) [8, 9]. Key genetic events in the genesis of OS are disruption of the TP53 and RB1 pathways [10, 11]. Whole genome DNA 
sequencing also recently identified that recurrent somatic structural variations in the ATRX and DLG2 genes are common in OS [8]. Loss or mutation of PRKAR1A, WWOX, TWIST, WRN, RECQL4 and amplification of c-FOS, and c-MYC have also been linked with OS [12]. It is becoming evident that epigenetic mechanisms also likely play a significant role in the initiation and maintenance of OS. Several genes have been reported to be epigenetically silenced in human OS, including WIF1, an antagonist of Wnt signaling $[13,14]$.

Active Wnt signaling is integral to normal osteoblast maturation, driving proliferation and differentiation [15]. Inhibition of the Wnt antagonist SOST to stimulate anabolic osteoblastic Wnt signaling is being developed for the treatment of the low bone mass of osteoporosis [16]. Of note, humans with sclerosteosis or the related van Buchem disease, both of which result from mutations reducing SOST expression or function, do not appear to be at increased risk of developing OS [17-22]. The report that WIF1 was epigenetically silenced in OS, and that its absence could augment OS in murine models, has potentially significant clinical implications for the treatment of osteoporosis with agents that activate or enhance Wnt signaling in bone [13].

To date, all OS epigenetic marker exploratory studies have been conducted in established human OS cell lines $[13,23,24]$. No studies have profiled primary OS tissue or very early passage cultures derived from OS tumor material. Embryonic stem cells (ESC) and tumor cells derived from primary xenograft models have been shown to undergo transcriptional and genetic drift with long-term culture [25, 26]. Culture driven changes in DNA methylation have also been demonstrated in ESCs, as well as divergence of methylation patterning in cancer cell lines and clinical specimens $[6,27$, 28]. Genetically engineered mouse models of human OS that recapitulate the features of human OS subtypes enable the study of primary and metastatic disease in low passage 
cell cultures $[29,30]$. Studying OS epigenetic signatures in these primary cultures may provide a closer representation of OS than has previously been possible.

We have made use of primary OS cell cultures derived from mouse OS models and normal osteoblasts to understand the regulation of Wif1. We have coupled this with human OS cell lines and transcriptional profiles of human OS. Our results demonstrate that Wif1 expression is not epigenetically inactivated by DNA methylation in mouse or human OS cells as previously reported. We propose that Wif1 expression levels mark tumors that are less differentiated and more fibroblastic/pre-osteoblastic without consequences for their tumorigenicity. 


\section{Materials and Methods}

\section{Cells}

All cells, unless otherwise specified, were grown in $\alpha$-modified Eagle's minimal ( $\alpha \mathrm{MEM})$ medium supplemented with $10 \%$ fetal bovine serum, $2 \mathrm{mM}$ GlutaMAX, and penicillinstreptomycin (normal growth media) at $37^{\circ} \mathrm{C}$ in a humidified atmosphere with $5 \% \mathrm{CO}_{2}$.

Low passage mouse OS cell cultures and tumors were derived from Osx-Cre $p 53^{f / f l}$ $p R b^{f / f f l}$ mice on a C57BI/6 background (Cre:Lox) as previously described[30]. The Kusa4b10 cell line was used in the undifferentiated basal state as a source of preosteoblast cells [31]. Mature osteoblasts were derived by placing Kusa4b10 cells under in vitro osteoblast differentiation conditions for 21 days [31] by exposing cells to normal growth media supplemented with $1 \mu \mathrm{M}$ ascorbate. Cells were maintained for the times indicated with twice weekly media changes. Cells were exposed to normal growth media supplemented with $1 \mu \mathrm{M}$ ascorbate and $0.1 \mu \mathrm{M} \quad \beta$-Glycerophosphate disodium salt hydrate for Alizarin red staining assays [31]. Primary pre-osteoblast and osteoblast cells were derived from crushed femur/tibia/iliac crest bones from 5 or 8 week old C57BI/6 mice as previously described [32, 33]. Lineage -ve/low CD31-ve Sca-1+ve CD51+ve pre-osteoblast cells and Lineage -ve/low CD31-ve Sca-1-ve CD51+ve osteoblast cells were purified by flow cytometry (FACSAria, BD Biosciences). WT calvaria cells were derived from 2 day old C57BI/6 pups as previously described [34]. The human OS cell line MG63 was acquired from ATCC. The human OS cell lines SAOS-2, G-292 and SJSA-1, were a kind gift from Assoc/Prof Damian Myers (Department of Surgery, St. Vincent's Hospital, Fitzroy, Australia), who purchased them from ATCC.

\section{Bisulphite clonal sequencing}


Bisulphite clonal sequencing was performed as previously described [35, 36] with some modifications. Genomic DNA was extracted using a DNeasy Blood and Tissue kit (Qiagen) as per the manufacturer's instructions. Genomic DNA was bisulphite converted using an EZ DNA Methylation-Gold kit ${ }^{\mathrm{TM}}$ (ZYMO Research) according to the manufacturers instructions. Nested bisulphite clonal sequencing primers were designed using MethPrimer publicly available online software. Primer sequences recognizing bisulphite converted DNA that encompassed two overlapping regions of the locus are listed in Supplementary table 1. PCR reactions were conducted in triplicate each time and combined to reduce potential amplification bias. PCR fragments were cloned into a pGEM ${ }^{\circledR}-\mathrm{T}$ vector (Promega) and propogated in TOP10 chemically competent E.coli. Three to six clones from each sample were randomly chosen and sequenced.

\section{Drug treatments}

5-aza-2'-deoxycytidine (5Aza) (Sigma Aldrich) was applied at 100nM in mouse cells or $5 \mu \mathrm{M}$ in human cells every 24 hours for 3 consecutive days. Trichostatin A (TSA) (Upstate, Millipore) was applied $(100 \mathrm{ng} / \mathrm{ml})$ for 24 hours either alone or in combination with 5 Aza in the final 24 hours of a 3-day assay.

\section{RNA extraction, cDNA synthesis, QPCR}

Total RNA used for microarray analyses was extracted using TRIzol reagent (Ambion). The aqueous RNA phase was isolated by chloroform separation and further purified by an RNeasy mini column kit (Qiagen) as per the manufacturers instructions. Total RNA used for QPCR analyses was extracted using an RNeasy mini or micro column kit (Qiagen) as per the manufacturers instructions. cDNA was synthesized using an AffinityScript QPCR cDNA synthesis kit (Agilent) as per the manufacturers instructions. 
Gene expression was quantified by realtime PCR (QPCR) using SYBR Green (Brilliant II SYBR ${ }^{\circledR}$ Green, Agilent) and oligonucleotide primers with a Mx3000P thermocycler (Stratagene) with MxPro software (Stratagene). Oligonucleotide primer sequences are listed in Supplementary table 1. Gene relative expression quantitation was calculated using the 2- $\Delta \mathrm{CT}$ method, normalized to Hprt expression. Primer specificity was verified by genome primer sequence Blast analysis, product sequencing and dissociation melt curve analysis.

\section{Microarray analyses}

RNA from mouse Cre:Lox fibroblastic OS cell cultures, pre-osteoblastic cells (undifferentiated Kusa4b10 cells) and osteoblast cells (derived by in vitro differentiation of Kusa4b10 cells) cells were hybridized to Affymetrix Mouse Gene 1.0ST microarrays at the Ramaciotti Centre for Gene Function Analysis at the University of New South Wales, Australia. The raw data has been uploaded to the Gene Expression Omnibus (GEO). Publicly available gene expression data from human OS samples and mouse Cre:Lox (fibroblastic) and shRNA (osteoblastic) OS subtype tumors were retrieved from GEO (accession numbers GSE30699 [37] and GSE38742 [29]). Raw data were normalized using RMA in GenePattern[38]. Probes were considered detected if expression was greater than the median of the control probes. Differentially expressed genes were analyzed using the LIMMA algorithm [39].

\section{Chromatin immunoprecipitation (ChIP)}

ChIP assays were performed as previously described [36, 40, 41]. ChIP assays were performed on three different mouse OS cell cultures and were compared to three independently derived samples each of pre-osteoblast and osteoblast cells derived from 
Kusa4b10 cells. Antibodies directed against H3K4trimethylation (Active Motif, No.39159), H3K27trimethylation (Millipore, No.07-449), diacetylated H3 (K9/K14) (Millipore, No.06-599) and normal rabbit IgG (Millipore, No.12-370) were used. Enrichment was quantified by QPCR. ChIP relative enrichment was determined by the 2$\Delta^{\mathrm{CT}(\text { bound-input) }}$ method and normalized to a control region in the Gapdh gene. Mean relative enrichment was determined from 3 independent osteoblast and pre-osteoblast samples, compared to 3 different mouse OS cell cultures.

\section{Statistical analyses}

Experiments are represented as mean \pm SEM (error bars) calculated from a minimum of two biological replicates unless otherwise stated. Student's t test was used to compare two groups and one-way ANOVA was used to compare a response over multiple time points. In all analyses, statistical significance was $p<0.05$. Prism 6.0 e software was used for analyses. 


\section{Results}

\section{Wif1 is downregulated in mouse OS}

To identify OS targets that are epigenetically deregulated we performed gene expression profiling of three independent early passage primary mouse OS cell cultures $(494 \mathrm{H}, 493 \mathrm{H}, 716 \mathrm{H})$ and mouse osteoblasts. The OS cell cultures were established from a mouse model of fibroblastic OS generated by osteoblast restricted deletion of Trp53 and $R b 1$ [30] and were less than 8 passages from isolation from the primary tumor. Comparison of significantly differentially expressed genes (absolute log fold change $>1.5$ and $p<0.05)$ identified 789 transcripts that are deregulated in OS compared to osteoblasts that were derived by differentiation of pre-osteoblastic Kusa4b10 cells (Fig. 1A). Of interest, we noted that Wif1 was one of the targets significantly downregulated in the murine OS cells (Fig. 1A), consistent with that reported in human OS [13, 14]. Independent profiling of primary mouse OS cell cultures and primary whole mouse OS tumors confirmed that Wif1 was repressed in OS cells (Fig. 1B-C). Wif1 expression was reduced in OS cells when compared to in vitro differentiated osteoblasts and FACSisolated mature osteoblasts from wildtype (WT) mouse long bones (Fig. 1B-C). Taken together, the mouse OS cells exhibit a deregulated transcriptome, and Wif1 is downregulated in murine OS cells consistent with findings in human OS [13, 14].

\section{Low expression of Wif1 in OS cells is controlled independently of DNA methylation}

WIF1 has been reported to be epigenetically silenced by DNA methylation in human OS $[13,14]$. As the transcriptional regulation of Wif1 in OS was conserved across species, we sought to establish if it was also epigenetically conserved. Surprisingly, however, bisulphite clonal sequencing of the Wif1 CpG island promoter region showed the locus is hypomethylated in mouse OS cells, similar to profiles in 
osteoblast cells and pre-osteoblast cells derived from Kusa4b10 cells (Fig. 2A). In contrast to the hypomethylated Wif1 locus, the Line-1 element in the OS cells was heavily methylated as expected[42], demonstrating the sensitivity of the assay (Supplementary Figure 1). The Wif1 hypomethylated status in mouse osteoblasts and primary OS cell cultures also contrasted with that previously reported in human OS. Consistent with the hypomethylated status of the Wif1 locus in murine OS, treatment with the demethylating agent 5-aza-2'-deoxycytidine (5Aza) failed to induce Wif1 expression (Fig. 2B). Treatment with the HDAC inhibitor Trichostatin A (TSA), however, elicited a strong induction of Wif1 expression in the mouse OS cultures. The level of induction of Wif1 was not further enhanced by the combined treatment of 5Aza with TSA (Fig. 2B), supporting the conclusion that Wif1 silencing in mouse OS cells is not driven by DNA methylation. TSA and 5Aza treatment of pre-osteoblastic Kusa4b10 cells and primary calvarial osteoblastic cells elicited similar Wif1 expression responses to the mouse OS cells (Fig. 2C-D). The observed equivalent induction in Wif1 expression suggested similar epigenetic mechanisms may control Wif1 in OS cells and normal osteoblastic cells.

WIF1 has been shown to be responsive to 5Aza in several human OS cell lines $[13,14]$, although its responsiveness to HDAC inhibition was not tested. The differential methylation of $4 \mathrm{CpG}$ dinucleotides located $200 \mathrm{bp}$ to $500 \mathrm{bp}$ upstream from the transcription start site was proposed to mediate WIF1 silencing in human OS cells [13]. We treated four different human OS cell lines (SAOS-2, G292, MG63, SJSA-1) with TSA and found WIF1 expression was rapidly induced, similar to results obtained from mouse OS cultures (Fig. 2E). Surprisingly, we failed to reproduce the robust induction in WIF1 expression in response to $5 \mathrm{Aza}$ treatment that has been previously reported, despite using comparable treatment conditions $(5 \mu \mathrm{M}$ over 3 days) $[13,14]$. Furthermore, combined treatment with 5Aza together with TSA failed to induce expression of WIF1 
significantly beyond levels achieved by TSA treatment alone (Fig. 2E). Collectively the results from murine and human OS cells indicated that methylation may not be involved in regulating WIF1 expression in human OS cells.

\section{A hypoacetylated bivalent chromatin state controls Wif1 expression}

Robust induction of Wif1 expression in mouse and human OS cell lines with TSA treatment suggested a repressive histone chromatin state was mechanistically involved in Wif1 silencing. To examine the histone modification status of Wif1 in OS we mapped the relative enrichment of the repressive histone mark H3K27trimethylation (H3K27tri) and the active histone marks $\mathrm{H} 3 \mathrm{~K} 4$ trimethylation (H3K4tri) and $\mathrm{H} 3$ diacetylation of $\mathrm{K} 9 / \mathrm{K} 14(\mathrm{H} 3 \mathrm{Ac})$ across the Wif1 locus in three primary mouse OS cell cultures and normal osteoblast and pre-osteoblast cells using chromatin immunoprecipitation (ChIP). Wif1 silencing in OS cells correlated with higher enrichment of the repressive H3K27tri mark and lower enrichment of the active H3Ac mark within 400bp of the TSS in all three mouse OS tumors compared to normal osteoblasts (Fig. 3). Interestingly, both OS cells and normal osteoblasts showed a similar enrichment of the active H3K4tri mark across the Wif1 locus, indicating the silenced Wif1 locus is bivalently marked in OS cells. H3Ac mapping of pre-osteoblast cells demonstrated that normal osteoblast maturation is associated with a gain in H3Ac at the Wif1 locus (Fig. 3). The pre-osteoblasts had a similar H3Ac landscape to OS cells, consistent with both cell types lacking Wif1 expression (Fig. 3, Fig. 1 and Fig. 5A-B).

\section{Wif1 expression marks mature osteoblastic differentiated states}

Wnt signaling plays an important role in normal osteoblast differentiation [15] and developmentally poised genes are characteristically bivalently marked [43, 44]. We hypothesized that Wif1 expression in OS may be reduced due to the differentiation stage of the tumor. Microarray profiling showed the osteoblast gene expression profile in the 
mouse OS cells mimicked the osteoblastic patterning in normal pre-osteoblastic undifferentiated Kusa4b10 cells (Fig. 4A-B). Low expression of Wif1 in pre-osteoblastic cells correlated with low expression of Phex, Bglap, Dmp1 and Sost, genes that mark late stages of osteoblast maturation. As pre-osteoblastic cells were induced to maturation, a gain in Wif1 expression coincided with increased expression of welldefined markers of osteoblast differentiation (Fig. 4A). A similarly repressed mature osteoblastic gene expression profile, with reduced Wif1 expression, was evident when the fibroblastic OS cells were compared to the in vitro differentiated mature osteoblasts (Fig. 4B).

The mouse OS cell cultures used in our analyses were obtained from a model of OS (Cre:Lox) that most closely approximates the fibroblastic or undifferentiated form of OS in humans $[29,30]$. We recently developed a new mouse model of OS generated by shRNA driven knockdown of Trp53 in the osteoblast lineage [29]. Histological, QPCR, and FACS cell surface profile analyses of tumors derived from the shRNA OS model were all characteristic of the osteoblastic OS subtype. The tumor cells in the Cre:lox model are enriched in pre-osteoblasts whilst those derived from the shRNA OS model are predominantly mature osteoblasts. Interestingly, microarray profiling identified expression of Wif1 as one of the key genes to distinguish the osteoblastic and fibroblastic OS subtype models [29] (Fig. 4C). Reduced Wif1 expression in the fibroblastic OS cells correlated with the repressed mature osteoblastic gene profile (Sost, Dmp1, Phex, Bglap) evident in these OS cells [29] (Fig. 4C).

To further examine the association of WIF1 expression with osteoblast differentiation stage in OS we examined the relationship between WIF1 expression and markers of osteoblastic differentiation in a previously published human OS microarray dataset [37]. WIF1 expression was low in most tumors, however tumors that did express WIF1 clustered in mature tumor phenotypes, coincident with other markers of the mature 
osteoblastic phenotype (Fig. 4D). The segregation of WIF1 expression with osteoblastic markers of late stages of maturation was consistent with a previous report in human OS [13]. These data suggest that WIF1 expression status may mark later stages of osteoblast differentiation and therefore distinguishes poorly differentiated OS tumors from more differentiated OS tumors.

\section{Induction of Wif1 expression in OS cells under differentiation conditions}

To further examine whether the heterogeneous Wif1 expression pattern seen in OS tumors is driven by their osteoblastic differentiation status, we examined Wif1 expression during normal osteoblast differentiation. Under in vitro osteoblastic differentiation conditions, Wif1 expression in the Kusa4b10 pre-osteoblastic cell line was almost undetectable in the early stages of differentiation when these cells retain adipogenic potential (Fig. 5A). As lineage commitment and differentiation proceeded there was a robust increase in Wif1 expression levels. The increase in Wif1 expression paralleled the increased expression of classic markers of osteoblast maturation such as Pthr1 and Bglap (Fig. 5A). Similarly, expression profiling of primary FACS isolated immature pre-osteoblast cells and mature osteoblast cells isolated from WT mouse long bones demonstrated Wif1 expression levels could distinguish mature osteoblasts from immature pre-osteoblast cells, along with other late markers including Pthr1 and Bglap (Fig. 5B). This demonstrates that Wif1 expression is a marker of mature osteoblast cells, consistent with findings in human osteoblast cells [13].

If Wif1 expression marks the maturation stage at which the OS cell is blocked, we reasoned that Wif1 expression should be increased in OS cells if they could be forced into a more mature differentiation stage. We placed four primary mouse OS cell cultures and four human OS cell lines under in vitro osteoblastic differentiation conditions. As evidenced by increased alizarin red staining of mineralized nodules, all of 
the human and mouse OS cell lines underwent maturation to some extent (Fig. 5C-D and Supplementary Fig. 2A-B). Correspondingly, we noted increased Wif1 expression in all cultures and cell lines as they differentiated (Fig. 5E and Supplementary Fig. 2C), similar to pre-osteoblastic cells undergoing maturation. Collectively the results from mouse and human OS and normal osteoblasts demonstrates that WIF1 marks late stages in osteoblast maturation and can stratify OS subtypes based on differentiation status. 


\section{Discussion:}

Changes in gene expression during tumorigenesis can be mediated by a number of mechanisms. Of these, DNA methylation is becoming increasingly associated with silencing of tumor suppressor genes. One attractive feature of DNA methylation is the possible reversal of this state using small molecule inhibitors. An understanding of the key targets for DNA-methylation in OS may provide a rationale for the application of demethylating agents in this tumor type. Additionally, a better understanding of the targets of DNA methylation may reveal important biology relevant to the initiation and maintenance of OS. WIF1 and other Wnt antagonists are frequently targeted for epigenetic inactivation by DNA methylation in many human cancers [45-49]. It had been proposed that DNA methylation dependent silencing of WIF1 in OS was biologically meaningful and its loss predisposed osteoblasts to transformation in experimental models [13]. The present work demonstrates WIF1 is not silenced by DNA methylation in human and mouse OS. Instead, silencing is driven by a histone modification chromatin profile that is conducive to activation by HDAC inhibition and normal osteoblastic maturation cues. WIF1 expression was shown to tightly couple with osteoblastic maturation. We propose that WIF1 expression is low/reduced in OS cells because they are stalled in the normal osteoblastic differentiation program.

WIF1 was previously reported to be epigenetically silenced by DNA methylation in human OS cell lines and tumors $[13,14]$. The present study, and a separate genomewide MeDIP-chip methylation profiling study of human OS cell lines [24], did not identify WIF1 as a differentially methylated target in OS. We believe these opposing results may stem from the type of assays performed by others $[13,14]$ and their interpretation of the results. Firstly, WIF1 expression was not activated by 5Aza treatment in all cell lines with a methylation signature $[13,14]$. Secondly, 4 CpG sites located in a region spanning $200 \mathrm{bp}$ to $500 \mathrm{bp}$ upstream of the WIF1 transcription start site were proposed to mediate 
the silencing. However, the methylation pattern did not appear to always correlate with the 5Aza mediated WIF1 response OS cell lines examined [13]. It was not examined whether 5Aza induced activation of WIF1 expression correlated with the demethylation of the $4 \mathrm{CpG}$ sites. These experiments would have mechanistically linked differential methylation of the $4 \mathrm{CpG}$ sites with transcriptional silencing.

5Aza has been shown to reactivate genes independent of DNA demethylation effects, including the Wnt antagonist $D K K 1$ in glioblastoma multiforme tumors [50]. The previous studies also did not examine the effects of HDAC inhibition [13, 14]. We have demonstrated that WIF1 can be activated by TSA and osteoblastic differentiation cues in OS cell lines previously examined (G292, SJSA-1, SAOS-2), two of which were reported to have WIF1 activation following 5Aza treatment. Recent evidence from a large scale study of 19 human OS cell lines [23] would suggest WIF1 methylation differences may not be functionally relevant. Despite being identified as a differentially methylated gene, WIF1 was not identified to be differentially expressed between the 19 OS cell lines and the normal osteoblast controls [23]. Finally, Kansara and colleagues reported that 5Aza treatment of the human OS cell lines induced osteoblastic differentiation as measured by increased alkaline phosphatase staining and mineralization [13]. In light of our current findings that WIF1 expression is tightly coupled to osteoblastic differentiation, 5Aza treatment may have activated WIF1 expression indirectly by inducing maturation of the OS cell lines rather than having a direct effect on WIF1. Indeed, pretreatment of human bone marrow stromal cells with $5 \mathrm{Aza}$ has been shown to enhance osteogenic differentiation [51].

WIF1 silencing has been shown to be driven by HDAC dependent mechanisms in glioblastoma multiforme tumors [50]. We have demonstrated that the silenced Wif1 promoter is hypoacetylated in OS compared to normal Wif1 expressing osteoblasts. Consistent with a histone modification driven mechanism of silencing, robust increases 
in Wif1 expression were achieved in OS and normal pre-osteoblast cells by treatment with TSA. Interestingly, we also demonstrate Wif1 is bivalently marked in OS cells. Bivalent states have been shown to mark developmentally poised genes in embryonic stem cells and are progressively lost during cellular differentiation [44]. In Wilms kidney tumors, bivalent domains marked the stalled developmental gene program that is upregulated during normal kidney differentiation, but is maintained in a repressed state in Wilms tumors, reminiscent of kidney progenitor cells [43]. Therefore it is perhaps not surprising that the Wif1 locus was bivalently marked in OS cells that are stalled in an osteoblastic differentiation program. These results demonstrate the importance of assessing the status of genes across a differentiation cascade. Most tumors show an impairment of differentiation and the patterns of gene expression may be a consequence of this rather than a driver of the tumor process.

The initial report of WIF1 being epigenetically inactivated by DNA methylation in OS [13] raised concerns for the clinical use of Wnt agonists in bone loss disorders due to the possible increased risk of OS development. Herein we show these concerns, as far as they relate to WIF1, are perhaps less significant than originally proposed. WIF1 expression, although often low/reduced in OS due to coupling of its expression with osteoblast maturation, is not epigenetically inactivated in OS by DNA methylation, but shares a chromatin state similar to osteoblasts undergoing normal stages of maturation. 


\section{Acknowledgements}

This work was supported by grants from the Cancer Council of Victoria (to C.W. and E.B.); NHMRC Career Development Award (to C.W.); Cure Cancer Australia Foundation Fellowship (to E.B); 5point foundation (to E.B); NHMRC project grant (to L.P.); NHMRC Senior Research Fellowship (to L.P); in part by the Victorian State Government Operational Infrastructure Support Program (to St. Vincent's Institute). C.W. is the Philip Desbrow Senior Research Fellow of the Leukaemia Foundation.

\section{Author Contributions}

EB and CW conceived the study; EB, ST, AG, AC, SB, AG, TM, MR, DS, LP, CW performed experiments and analyzed data; EB, TM, MR, LP, CW provided intellectual input and conceptual advice; EB and CW wrote the manuscript; All authors reviewed the manuscript.

Conflicts of interest: The authors declare no competing financial interest. 


\section{References}

[1] Allison DC, Carney SC, Ahlmann ER, Hendifar A, Chawla S, Fedenko A, Angeles C, Menendez LR. A meta-analysis of osteosarcoma outcomes in the modern medical era. Sarcoma 2012;2012: 704872.

[2] Janeway KA, Grier HE. Sequelae of osteosarcoma medical therapy: a review of rare acute toxicities and late effects. Lancet Oncol 2010;11: 670-8.

[3] Bacci G, Longhi A, Versari M, Mercuri M, Briccoli A, Picci P. Prognostic factors for osteosarcoma of the extremity treated with neoadjuvant chemotherapy: 15-year experience in 789 patients treated at a single institution. Cancer 2006;106: 1154-61.

[4] Bacci G, Longhi A, Fagioli F, Briccoli A, Versari M, Picci P. Adjuvant and neoadjuvant chemotherapy for osteosarcoma of the extremities: 27 year experience at Rizzoli Institute, Italy. Eur J Cancer 2005;41: 2836-45.

[5] Ji H, Ehrlich LI, Seita J, Murakami P, Doi A, Lindau P, Lee H, Aryee MJ, Irizarry RA, Kim K, Rossi DJ, Inlay MA, Serwold T, Karsunky H, Ho L, Daley GQ, Weissman IL, Feinberg AP. Comprehensive methylome map of lineage commitment from haematopoietic progenitors. Nature 2010;467: 338-42.

[6] Meissner A, Mikkelsen TS, Gu H, Wernig M, Hanna J, Sivachenko A, Zhang X, Bernstein BE, Nusbaum C, Jaffe DB, Gnirke A, Jaenisch R, Lander ES. Genome-scale DNA methylation maps of pluripotent and differentiated cells. Nature 2008;454: 766-70.

[7] Wamstad JA, Alexander JM, Truty RM, Shrikumar A, Li F, Eilertson KE, Ding H, Wylie JN, Pico AR, Capra JA, Erwin G, Kattman SJ, Keller GM, Srivastava D, Levine SS, Pollard KS, Holloway AK, Boyer LA, Bruneau BG. Dynamic and coordinated epigenetic regulation of developmental transitions in the cardiac lineage. Cell 2012;151: 206-20.

[8] Chen X, Bahrami A, Pappo A, Easton J, Dalton J, Hedlund E, Ellison D, Shurtleff S, Wu G, Wei L, Parker M, Rusch M, Nagahawatte P, Wu J, Mao S, Boggs K, Mulder H, Yergeau D, Lu C, Ding L, Edmonson M, Qu C, Wang J, Li Y, Navid F, Daw NC, Mardis ER, Wilson RK, Downing JR, Zhang J, Dyer MA, St. Jude Children's Research HospitalWashington University Pediatric Cancer Genome P. Recurrent somatic structural variations contribute to tumorigenesis in pediatric osteosarcoma. Cell Rep 2014;7: 10412.

[9] Stephens PJ, Greenman CD, Fu B, Yang F, Bignell GR, Mudie LJ, Pleasance ED, Lau KW, Beare D, Stebbings LA, McLaren S, Lin ML, McBride DJ, Varela I, NikZainal S, Leroy C, Jia M, Menzies A, Butler AP, Teague JW, Quail MA, Burton J, Swerdlow H, Carter NP, Morsberger LA, lacobuzio-Donahue C, Follows GA, Green AR, Flanagan AM, Stratton MR, Futreal PA, Campbell PJ. Massive genomic rearrangement acquired in a single catastrophic event during cancer development. Cell 2011;144: 2740.

[10] Birch JM, Alston RD, McNally RJ, Evans DG, Kelsey AM, Harris M, Eden OB, Varley JM. Relative frequency and morphology of cancers in carriers of germline TP53 mutations. Oncogene 2001;20: 4621-8.

[11] Wadayama B, Toguchida J, Shimizu T, Ishizaki K, Sasaki MS, Kotoura Y, Yamamuro T. Mutation spectrum of the retinoblastoma gene in osteosarcomas. Cancer Res 1994;54: 3042-8.

[12] Ng AJ, Mutsaers AJ, Baker EK, Walkley CR. Genetically engineered mouse models and human osteosarcoma. Clin Sarcoma Res 2012;2: 19.

[13] Kansara M, Tsang M, Kodjabachian L, Sims NA, Trivett MK, Ehrich M, Dobrovic A, Slavin J, Choong PF, Simmons PJ, Dawid IB, Thomas DM. Wnt inhibitory factor 1 is epigenetically silenced in human osteosarcoma, and targeted disruption accelerates osteosarcomagenesis in mice. J Clin Invest 2009;119: 837-51. 
[14] Rubin EM, Guo Y, Tu K, Xie J, Zi X, Hoang BH. Wnt inhibitory factor 1 decreases tumorigenesis and metastasis in osteosarcoma. Mol Cancer Ther 2010;9: 731-41.

[15] Monroe DG, McGee-Lawrence ME, Oursler MJ, Westendorf JJ. Update on Wnt signaling in bone cell biology and bone disease. Gene 2012;492: 1-18.

[16] Kim JH, Liu X, Wang J, Chen X, Zhang H, Kim SH, Cui J, Li R, Zhang W, Kong Y, Zhang J, Shui W, Lamplot J, Rogers MR, Zhao C, Wang N, Rajan P, Tomal J, Statz J, Wu N, Luu HH, Haydon RC, He TC. Wnt signaling in bone formation and its therapeutic potential for bone diseases. Ther Adv Musculoskelet Dis 2013;5: 13-31.

[17] Balemans W, Ebeling M, Patel N, Van Hul E, Olson P, Dioszegi M, Lacza C, Wuyts W, Van Den Ende J, Willems P, Paes-Alves AF, Hill S, Bueno M, Ramos FJ, Tacconi P, Dikkers FG, Stratakis C, Lindpaintner K, Vickery B, Foernzler D, Van Hul W. Increased bone density in sclerosteosis is due to the deficiency of a novel secreted protein (SOST). Hum Mol Genet 2001;10: 537-43.

[18] Balemans W, Patel N, Ebeling M, Van Hul E, Wuyts W, Lacza C, Dioszegi M, Dikkers FG, Hildering P, Willems PJ, Verheij JB, Lindpaintner K, Vickery B, Foernzler D, Van Hul W. Identification of a $52 \mathrm{~kb}$ deletion downstream of the SOST gene in patients with van Buchem disease. J Med Genet 2002;39: 91-7.

[19] Brunkow ME, Gardner JC, Van Ness J, Paeper BW, Kovacevich BR, Proll S, Skonier JE, Zhao L, Sabo PJ, Fu Y, Alisch RS, Gillett L, Colbert T, Tacconi P, Galas D, Hamersma $\mathrm{H}$, Beighton $\mathrm{P}$, Mulligan J. Bone dysplasia sclerosteosis results from loss of the SOST gene product, a novel cystine knot-containing protein. Am J Hum Genet 2001;68: 577-89.

[20] Hamersma H, Gardner J, Beighton P. The natural history of sclerosteosis. Clin Genet 2003;63: 192-7.

[21] Loots GG, Kneissel M, Keller H, Baptist M, Chang J, Collette NM, Ovcharenko D, Plajzer-Frick I, Rubin EM. Genomic deletion of a long-range bone enhancer misregulates sclerostin in Van Buchem disease. Genome Res 2005;15: 928-35.

[22] van Lierop AH, Hamdy NA, van Egmond ME, Bakker E, Dikkers FG, Papapoulos SE. Van Buchem disease: clinical, biochemical, and densitometric features of patients and disease carriers. J Bone Miner Res 2013;28: 848-54.

[23] Kresse SH, Rydbeck $H$, Skarn M, Namlos HM, Barragan-Polania AH, CletonJansen AM, Serra M, Liestol K, Hogendoorn PC, Hovig E, Myklebost O, Meza-Zepeda LA. Integrative analysis reveals relationships of genetic and epigenetic alterations in osteosarcoma. PLoS One 2012;7: e48262.

[24] Sadikovic B, Yoshimoto M, Al-Romaih K, Maire G, Zielenska M, Squire JA. In vitro analysis of integrated global high-resolution DNA methylation profiling with genomic imbalance and gene expression in osteosarcoma. PLoS One 2008;3: e2834.

[25] Daniel VC, Marchionni L, Hierman JS, Rhodes JT, Devereux WL, Rudin CM, Yung R, Parmigiani G, Dorsch M, Peacock CD, Watkins DN. A primary xenograft model of small-cell lung cancer reveals irreversible changes in gene expression imposed by culture in vitro. Cancer Res 2009;69: 3364-73.

[26] Narva E, Autio R, Rahkonen N, Kong L, Harrison N, Kitsberg D, Borghese L, Itskovitz-Eldor J, Rasool O, Dvorak P, Hovatta O, Otonkoski T, Tuuri T, Cui W, Brustle O, Baker D, Maltby E, Moore HD, Benvenisty N, Andrews PW, Yli-Harja O, Lahesmaa R. High-resolution DNA analysis of human embryonic stem cell lines reveals cultureinduced copy number changes and loss of heterozygosity. Nat Biotechnol 2010;28: 3717.

[27] Ehrich M, Turner J, Gibbs P, Lipton L, Giovanneti M, Cantor C, van den Boom D. Cytosine methylation profiling of cancer cell lines. Proc Natl Acad Sci U S A 2008;105: 4844-9. 
[28] Smiraglia DJ, Rush LJ, Fruhwald MC, Dai Z, Held WA, Costello JF, Lang JC, Eng C, Li B, Wright FA, Caligiuri MA, Plass C. Excessive CpG island hypermethylation in cancer cell lines versus primary human malignancies. Hum Mol Genet 2001;10: 1413-9.

[29] Mutsaers AJ, Ng AJ, Baker EK, Russell MR, Chalk AM, Wall M, Liddicoat BJ, Ho PW, Slavin JL, Goradia A, Martin TJ, Purton LE, Dickins RA, Walkley CR. Modeling distinct osteosarcoma subtypes in vivo using Cre:lox and lineage-restricted transgenic shRNA. Bone 2013;55: 166-78.

[30] Walkley CR, Qudsi R, Sankaran VG, Perry JA, Gostissa M, Roth SI, Rodda SJ, Snay E, Dunning P, Fahey FH, Alt FW, McMahon AP, Orkin SH. Conditional mouse osteosarcoma, dependent on p53 loss and potentiated by loss of Rb, mimics the human disease. Genes Dev 2008;22: 1662-76.

[31] Allan EH, Ho PW, Umezawa A, Hata J, Makishima F, Gillespie MT, Martin TJ. Differentiation potential of a mouse bone marrow stromal cell line. J Cell Biochem 2003;90: 158-69.

[32] Noll JE, Williams SA, Tong CM, Wang H, Quach JM, Purton LE, Pilkington K, To LB, Evdokiou A, Gronthos S, Zannettino AC. Myeloma plasma cells alter the bone marrow microenvironment by stimulating the proliferation of mesenchymal stromal cells. Haematologica 2014;99: 163-71.

[33] Semerad CL, Christopher MJ, Liu F, Short B, Simmons PJ, Winkler I, Levesque JP, Chappel J, Ross FP, Link DC. G-CSF potently inhibits osteoblast activity and CXCL12 mRNA expression in the bone marrow. Blood 2005;106: 3020-7.

[34] Takyar FM, Tonna S, Ho PW, Crimeen-Irwin B, Baker EK, Martin TJ, Sims NA. EphrinB2/EphB4 inhibition in the osteoblast lineage modifies the anabolic response to parathyroid hormone. J Bone Miner Res 2013;28: 912-25.

[35] Baker EK, El-Osta A. Epigenetic regulation of multidrug resistance 1 gene expression: profiling $\mathrm{CpG}$ methylation status using bisulphite sequencing. Methods Mol Biol 2010;596: 183-98.

[36] Baker EK, Johnstone RW, Zalcberg JR, El-Osta A. Epigenetic changes to the MDR1 locus in response to chemotherapeutic drugs. Oncogene 2005;24: 8061-75.

[37] Kuijjer ML, Namlos HM, Hauben EI, Machado I, Kresse SH, Serra M, LlombartBosch A, Hogendoorn PC, Meza-Zepeda LA, Myklebost O, Cleton-Jansen AM. mRNA expression profiles of primary high-grade central osteosarcoma are preserved in cell lines and xenografts. BMC Med Genomics 2011;4: 66.

[38] Irizarry RA, Hobbs B, Collin F, Beazer-Barclay YD, Antonellis KJ, Scherf U, Speed TP. Exploration, normalization, and summaries of high density oligonucleotide array probe level data. Biostatistics 2003;4: 249-64.

[39] Smyth GK. Linear models and empirical bayes methods for assessing differential expression in microarray experiments. Stat Appl Genet Mol Biol 2004;3: Article3.

[40] Harikrishnan KN, Chow MZ, Baker EK, Pal S, Bassal S, Brasacchio D, Wang L, Craig JM, Jones PL, Sif S, El-Osta A. Brahma links the SWI/SNF chromatin-remodeling complex with MeCP2-dependent transcriptional silencing. Nat Genet 2005;37: 254-64.

[41] Jurado S, Conlan LA, Baker EK, Ng JL, Tenis N, Hoch NC, Gleeson K, Smeets M, Izon D, Heierhorst J. ATM substrate Chk2-interacting Zn2+ finger (ASCIZ) Is a bifunctional transcriptional activator and feedback sensor in the regulation of dynein light chain (DYNLL1) expression. J Biol Chem 2012;287: 3156-64.

[42] Chalitchagorn K, Shuangshoti S, Hourpai N, Kongruttanachok N, Tangkijvanich $P$, Thong-ngam D, Voravud N, Sriuranpong V, Mutirangura A. Distinctive pattern of LINE-1 methylation level in normal tissues and the association with carcinogenesis. Oncogene 2004;23: 8841-6. 
[43] Aiden AP, Rivera MN, Rheinbay E, Ku M, Coffman EJ, Truong TT, Vargas SO, Lander ES, Haber DA, Bernstein BE. Wilms tumor chromatin profiles highlight stem cell properties and a renal developmental network. Cell Stem Cell 2010;6: 591-602.

[44] Bernstein BE, Mikkelsen TS, Xie X, Kamal M, Huebert DJ, Cuff J, Fry B, Meissner A, Wernig M, Plath K, Jaenisch R, Wagschal A, Feil R, Schreiber SL, Lander ES. A bivalent chromatin structure marks key developmental genes in embryonic stem cells. Cell 2006;125: 315-26.

[45] Ai L, Tao Q, Zhong S, Fields CR, Kim WJ, Lee MW, Cui Y, Brown KD, Robertson KD. Inactivation of Wnt inhibitory factor-1 (WIF1) expression by epigenetic silencing is a common event in breast cancer. Carcinogenesis 2006;27: 1341-8.

[46] Chan SL, Cui Y, van Hasselt A, Li H, Srivastava G, Jin H, Ng KM, Wang Y, Lee KY, Tsao GS, Zhong S, Robertson KD, Rha SY, Chan AT, Tao Q. The tumor suppressor Wnt inhibitory factor 1 is frequently methylated in nasopharyngeal and esophageal carcinomas. Lab Invest 2007;87: 644-50.

[47] Mazieres J, He B, You L, Xu Z, Lee AY, Mikami I, Reguart N, Rosell R, McCormick F, Jablons DM. Wnt inhibitory factor-1 is silenced by promoter hypermethylation in human lung cancer. Cancer Res 2004;64: 4717-20.

[48] Ramachandran I, Thavathiru E, Ramalingam S, Natarajan G, Mills WK, Benbrook DM, Zuna R, Lightfoot S, Reis A, Anant S, Queimado L. Wnt inhibitory factor 1 induces apoptosis and inhibits cervical cancer growth, invasion and angiogenesis in vivo. Oncogene 2012;31: 2725-37.

[49] Taniguchi H, Yamamoto H, Hirata T, Miyamoto N, Oki M, Nosho K, Adachi Y, Endo T, Imai K, Shinomura Y. Frequent epigenetic inactivation of Wnt inhibitory factor-1 in human gastrointestinal cancers. Oncogene 2005;24: 7946-52.

[50] Foltz G, Yoon JG, Lee H, Ma L, Tian Q, Hood L, Madan A. Epigenetic regulation of wnt pathway antagonists in human glioblastoma multiforme. Genes Cancer 2010;1: 81-90.

[51] El-Serafi AT, Oreffo RO, Roach HI. Epigenetic modifiers influence lineage commitment of human bone marrow stromal cells: Differential effects of 5-azadeoxycytidine and trichostatin A. Differentiation 2011;81: 35-41. 


\section{Figure Legends}

Figure 1: Wif1 expression is downregulated in mouse OS cells compared to mature osteoblasts. (A) Heatmap representation of 789 transcripts differentially expressed (absolute log fold change $>1.5$ and $p<0.05$ ) in mouse OS cell cultures compared to three independently derived mature osteoblast samples $(\mathrm{OB} 1,2,3)$ (in vitro differentiated pre-osteoblastic Kusa4b10 cells). The heatmap is colored based on relative values using the row minimum and row maximum. Wif1 is highlighted and is downregulated in mouse OS cells. (B) QPCR analysis of Wif1 expression levels in mature osteoblast samples (in vitro differentiated Kusa4b10 pre-osteoblastic cells) and mouse OS cell cultures. Mean relative expression \pm SEM ( $n=3-6)$. Asterix denotes statistical significance determined by Student's test, ${ }^{* *} p<0.01$. (C) QPCR analysis of Wif1 expression levels in primary osteoblastic cells (derived from WT mouse long bones) and whole mouse OS tumors. Mean relative expression \pm SEM ( $n=5-9)$. Asterix denotes statistical significance determined by Student's t test, ${ }^{* * * *} p<0.0001$.

Figure 2: Wif1 is hypomethylated in OS cells and is upregulated by HDAC inhibition. (A) Schematic of the Wif1 locus analyzed by bisulphite sequencing. The spatial positioning of the $\mathrm{CpG}$ dinucleotides assessed are represented as lollipops. The hypomethylation status of Wif1 in each culture is represented by the colored grids. Each row of boxes represents a single cloned allele. Each box represents a single CpG dinucleotide that is methylated (dark grey) or unmethylated (white). Each group of 3-6 cloned alleles represents an independent DNA sample derived from pre-osteoblastic cells (undifferentiated Kusa4b10 cells), osteoblast cells (in vitro differentiated Kusa4b10 cells) or 3 independent mouse OS cell cultures $(494 \mathrm{H}, 493 \mathrm{H}, 202 \mathrm{~V})$. (B-E) Treatment of 
OS and osteoblastic cells with inhibitors of HDACs and DNA methylation. Untreated cells $(U)$ were compared to cells treated with the HDAC inhibitor TSA $(T)$, the DNA methylation inhibitor 5-aza-2'-deoxycytidine (A), or a combination of both compounds $(A+T)$. Values represent mean Wif1 relative expression \pm SEM $(n=2-3)$. Asterix denotes statistical significance determined by Student's $\mathrm{t}$ test, ${ }^{*} p<0.05,{ }^{* *} p<0.01,{ }^{* * *} p<0.001$.

(B) Wif1 expression levels in mouse OS cell cultures. (C) Wif1 expression levels in Kusab410 pre-osteoblastic (Pre-OB) cells. (D) Wif1 expression levels in primary mouse calvarial osteoblastic (OB) cells. (E) WIF1 expression in human OS cells.

Figure 3: The Wif1 promoter in OS cells is associated with a bivalent H3K27tri/H3K4tri and reduced H3Ac histone modification state. Schematic of the mouse Wif1 locus with transcription start site (TSS) and translation start site (ATG) positioning shown based on the mouse mm8 genome build. H3K27tri, H3K4tri and H3Ac modifications were mapped across four regions (numbered 1-4, positions relative to ATG). Relative enrichment at the Wif1 locus was normalized to levels detected at a control locus region (Gapdh coding region). Values are mean relative enrichment \pm SEM for three osteoblast cell samples (OB) (in vitro differentiated Kusa4b10 cells), 3 preosteoblast cell samples (Pre-OB) (undifferentiated Kusa4b10 cells), and 3 different mouse OS cell cultures (OS); ${ }^{*} p<0.05,{ }^{* *} p<0.01$ derived by Student's t test.

Figure 4: Wif1 expression correlates with OS tumor subtype and maturity status. (A) Heatmap representation of osteoblastic marker gene set expression in mouse preosteoblastic cells (undifferentiated Kusa4b10 cells) and mature osteoblast cells (derived 
by in vitro differentiation of Kusa4b10 pre-osteoblastic cells). The heatmap is colored based on relative values using the row minimm and row maximum. (B) Heatmap representation of osteoblastic marker gene set expression in mouse fibroblastic (Cre:Lox) OS cell cultures and mature osteoblast cells (derived by in vitro differentiation of Kusa4b10 pre-osteoblastic cells). The heatmap is colored based on relative values using the row minimm and row maximum. (C) Heatmap representation of osteoblastic marker gene set expression in OS tumors derived from mouse osteoblastic (shRNA) and mouse fibroblastic (Cre:Lox) OS models. The heatmap is colored based on relative values using the row minimum and row maximum. (D) WIF1 expression segregates mature osteoblastic phenotypes from immature/fibroblastic OS phenotypes. Heatmap representation of osteoblastic marker gene set expression in a panel of primary human fibroblastic (yellow circle), chondroblastic (blue circle) and osteoblastic (black circle) OS tumors. Samples were clustered by Euclidian distance and colored based on relative values using the row minimum and row maximum.

Figure 5: Wif1 expression is acquired late in normal osteoblast lineage commitment and is induced in mouse and human OS cells under osteoblastic maturation conditions. (A-B) QPCR analysis of Wif1 expression and early (Runx2, Sp7), intermediate (Pth1r, Alpl) and late (Bglap) osteoblastic gene expression markers. Values are mean relative expression \pm SEM. Asterix denotes statistical significance determined by one-way AVOVA or Student's t test, ${ }^{*} p<0.05,{ }^{* *} p<0.01,{ }^{* * *} p<0.001,{ }^{* * * *}$ $p<0.0001$. (A) Wif1 and osteoblastic gene expression profiles in pre-osteoblastic Kusa4b10 cells undergoing in vitro osteoblast differentiation $(n=3)$. (B) Wif1 and osteoblastic gene expression profiles in pre-osteoblast (Pre-OB) and osteoblast (OB) cells isolated from 8 week old wild type C57BL6 mouse long bones ( $n=4-7)$. (C) Alizarin red staining of mineralized nodules in mouse $(716 \mathrm{H}$ and $493 \mathrm{H})$ and human (SAOS-2, 
SJSA-1) OS cell cultures grown under osteoblastic conditions over 21 days. (D) Quantitation of mineralization in mouse $(716 \mathrm{H}$ and $493 \mathrm{H})$ and human OS (SAOS-2, SJSA-1) cell culture over 21 days. Values are mean eluted alizarin red concentration $(\mu \mathrm{M}) \pm \mathrm{SEM}$. Data is from 5 separate assays from an individual experiment and is representative of 2 independent experiments. Asterix denotes statistical significance determined by one-way AVOVA, ${ }^{*} p<0.05,{ }^{* *} p<0.01,{ }^{* * * *} p<0.0001$. (E) Quantitation of Wif1 expression in mouse $(716 \mathrm{H}$ and $493 \mathrm{H})$ and human OS (SAOS-2, SJSA-1) cell cultures grown under osteoblastic conditions over 21 days. Values are mean fold change in Wif1 expression (compared to day 0$) \pm$ SEM ( $n=2-3$ ). Asterix denotes statistical significance determined by one-way AVOVA, ${ }^{*} p<0.05,{ }^{* *} p<0.01,{ }^{* * *} p<0.0001$. 
Figure 1

A

\begin{tabular}{cc}
$\begin{array}{c}\text { Osteoblastic } \\
\text { Cells }\end{array}$ & OS \\
\cline { 2 - 2 } & Cells
\end{tabular}

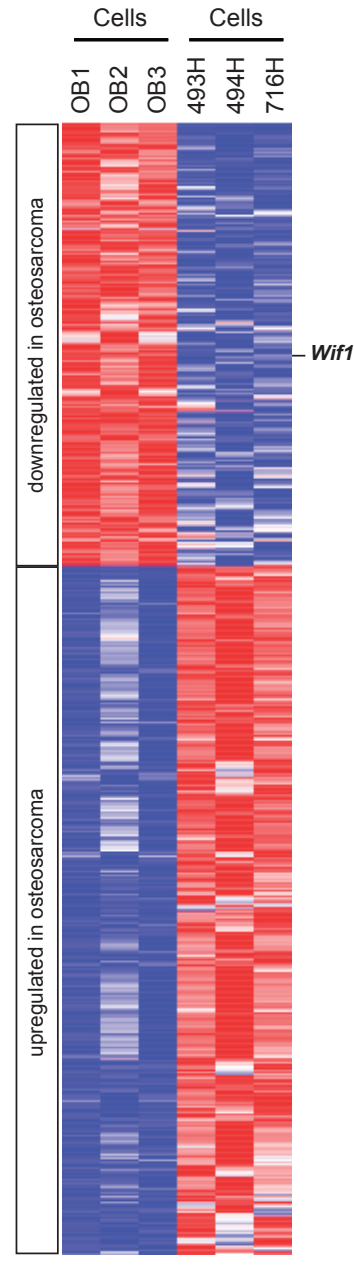

B
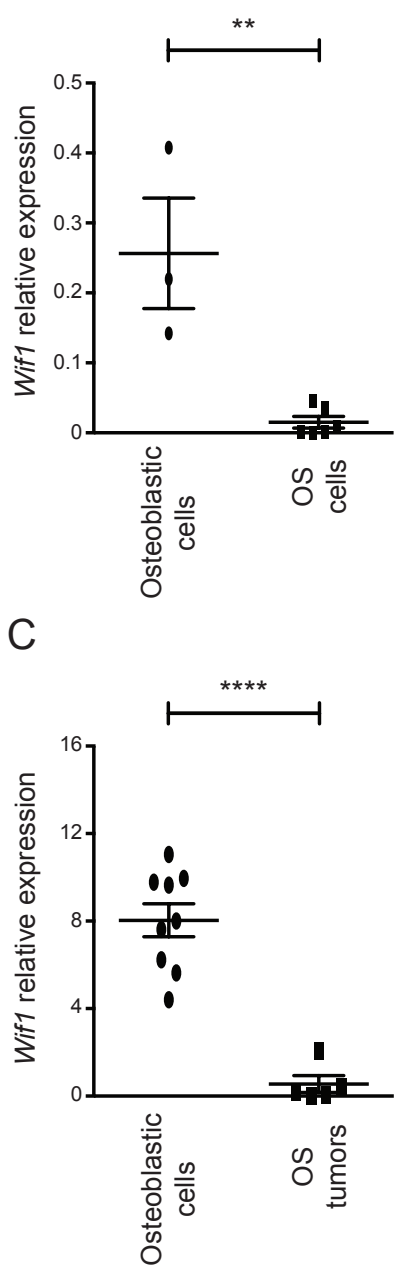
Figure 2

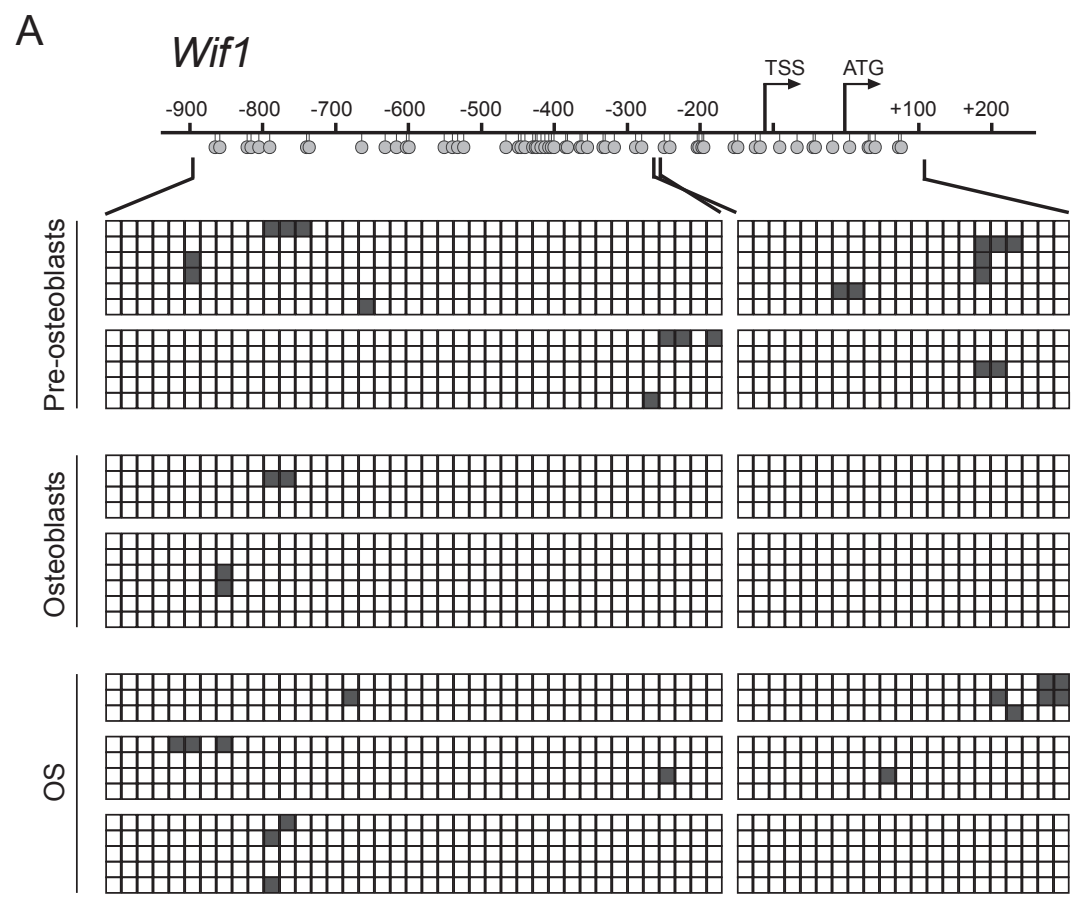

B
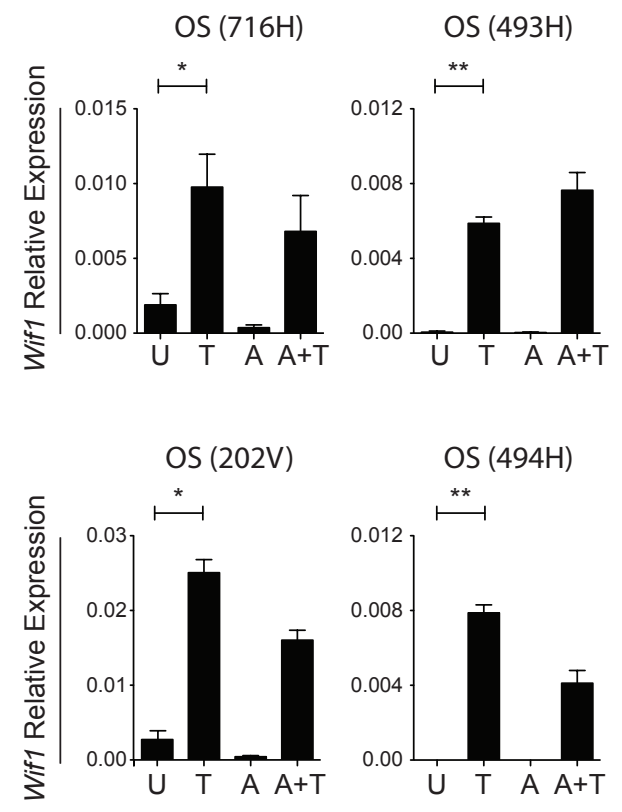

C

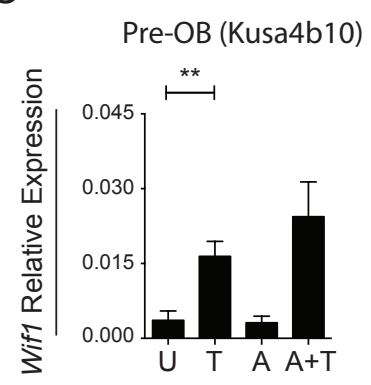

D

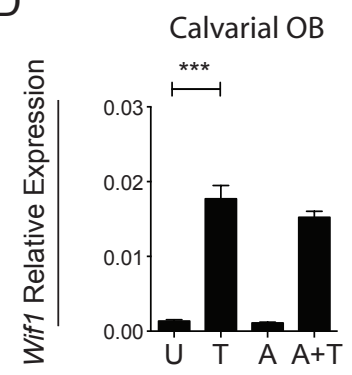

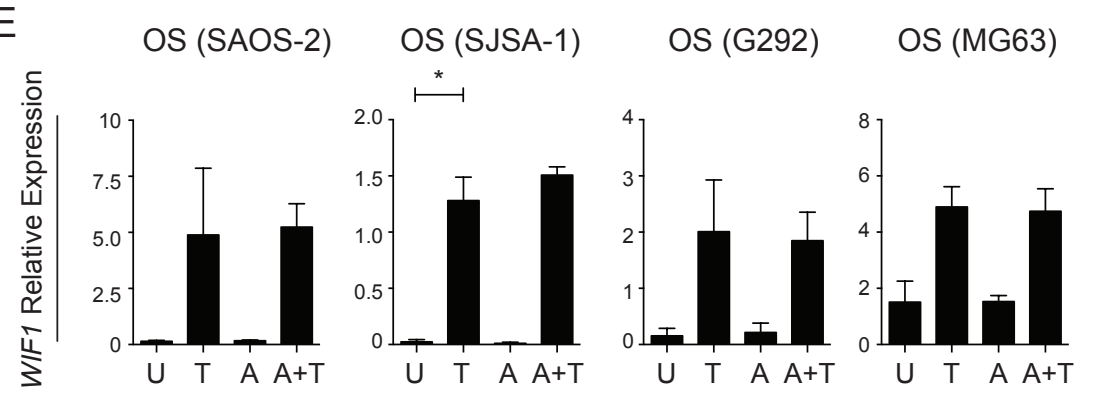


Figure 3
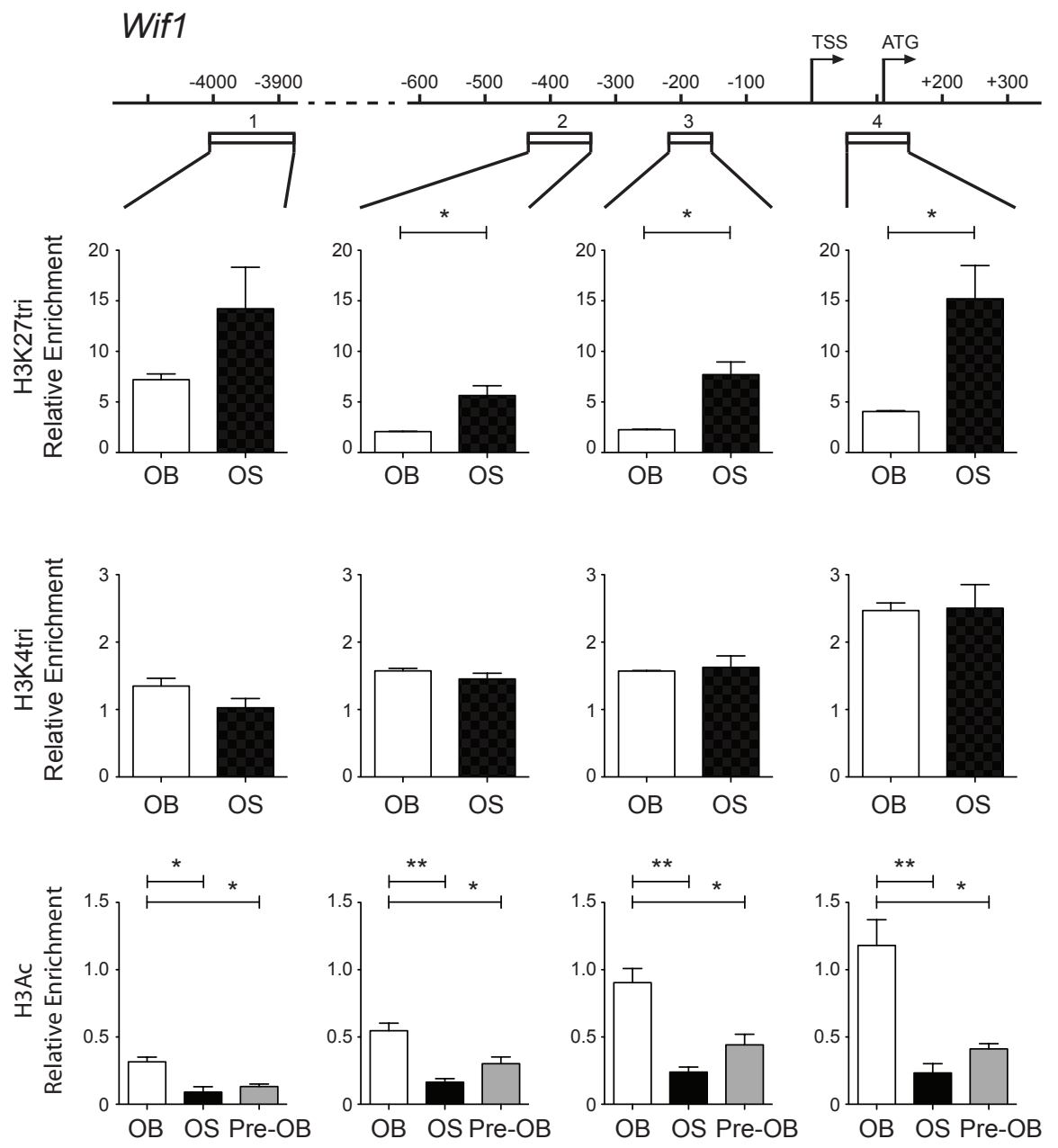
Figure 4

A

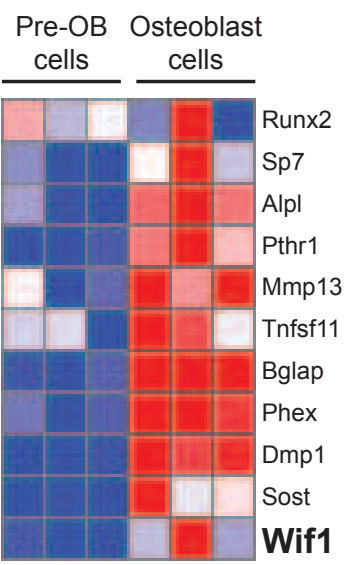

B Fibroblastic Osteoblast

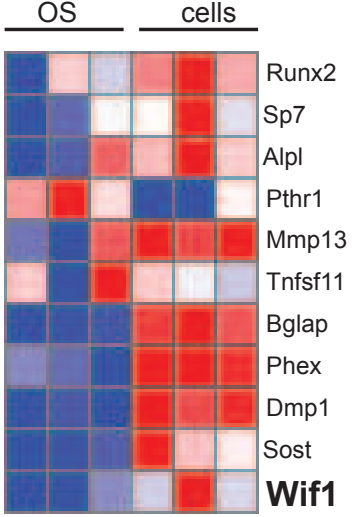

C

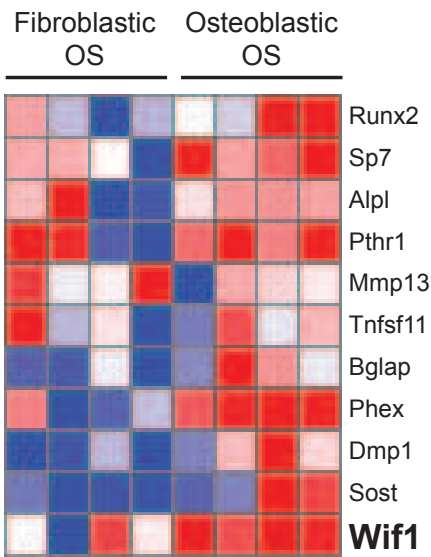

D

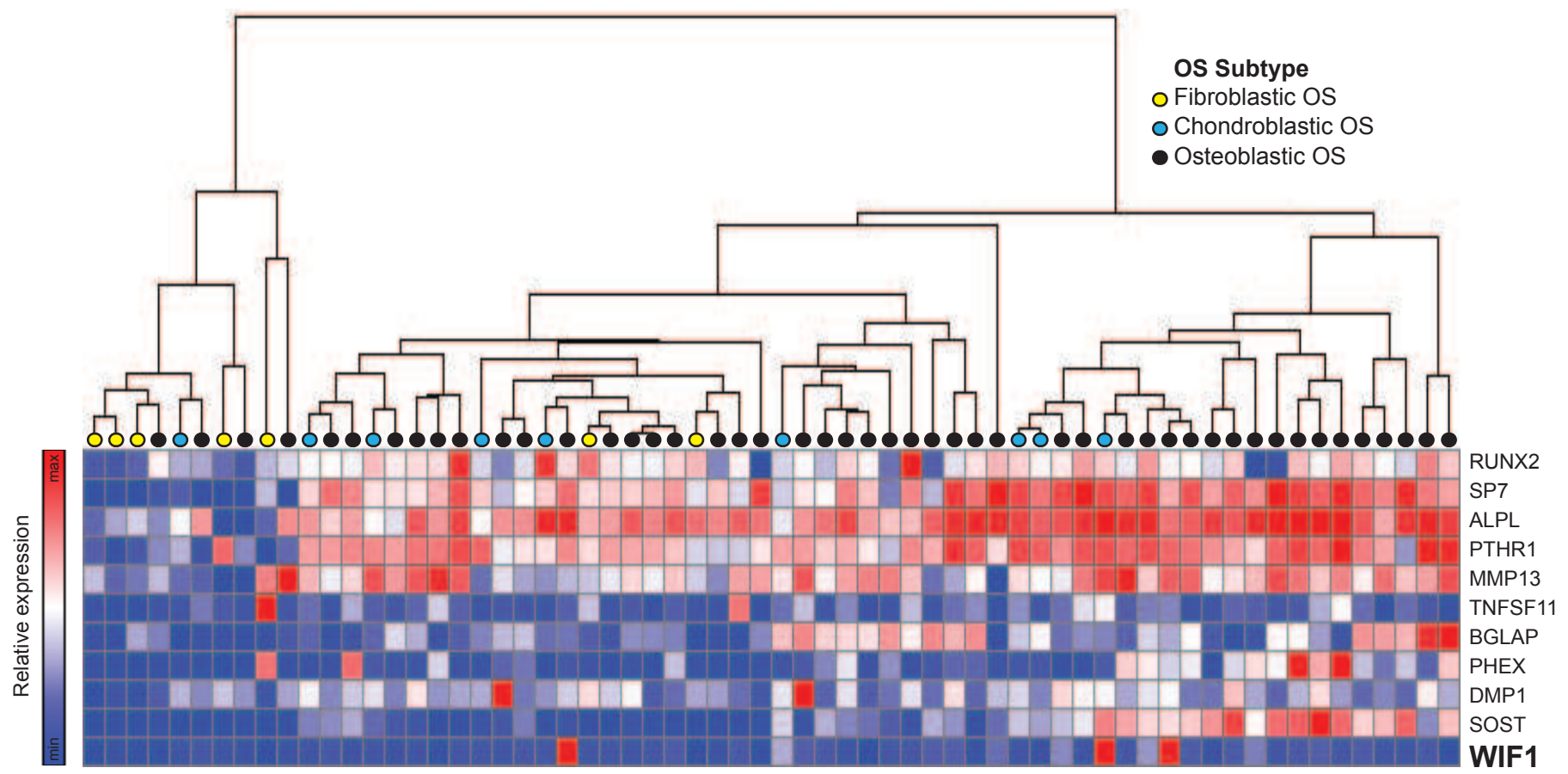


Figure 5

A
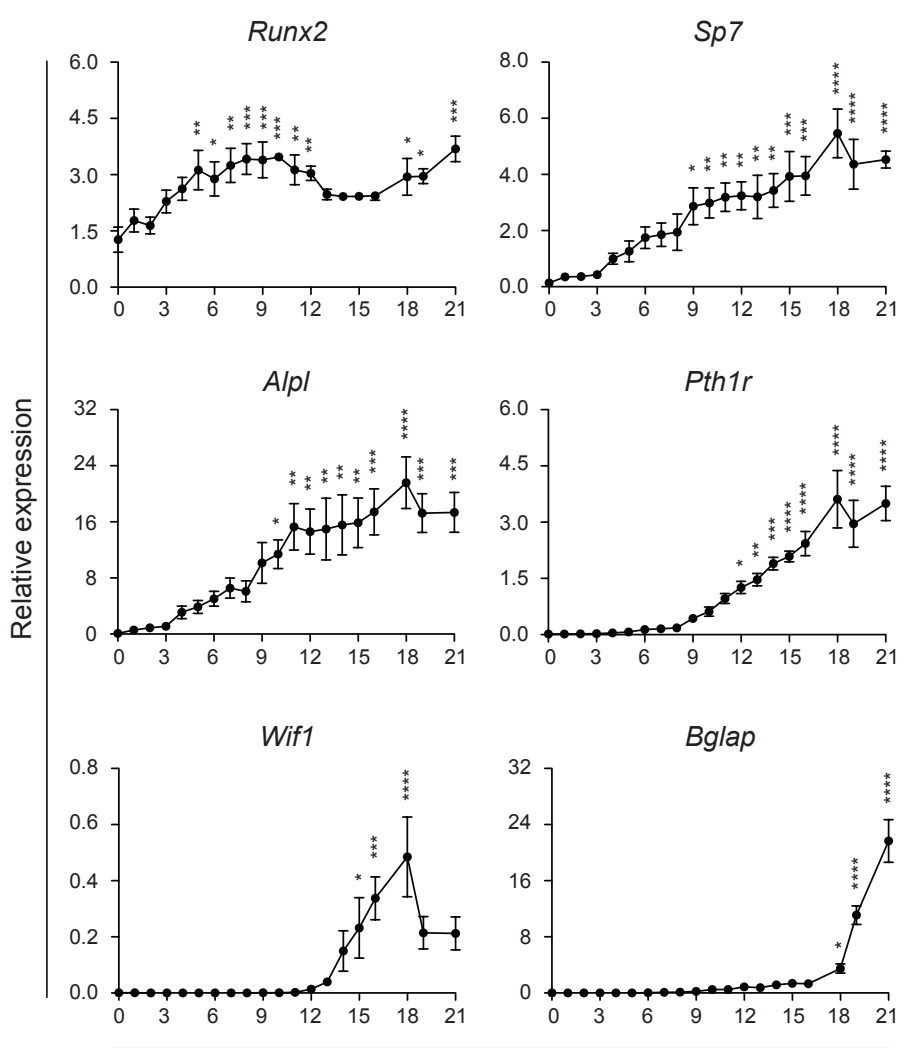

Days post-differentiation

C

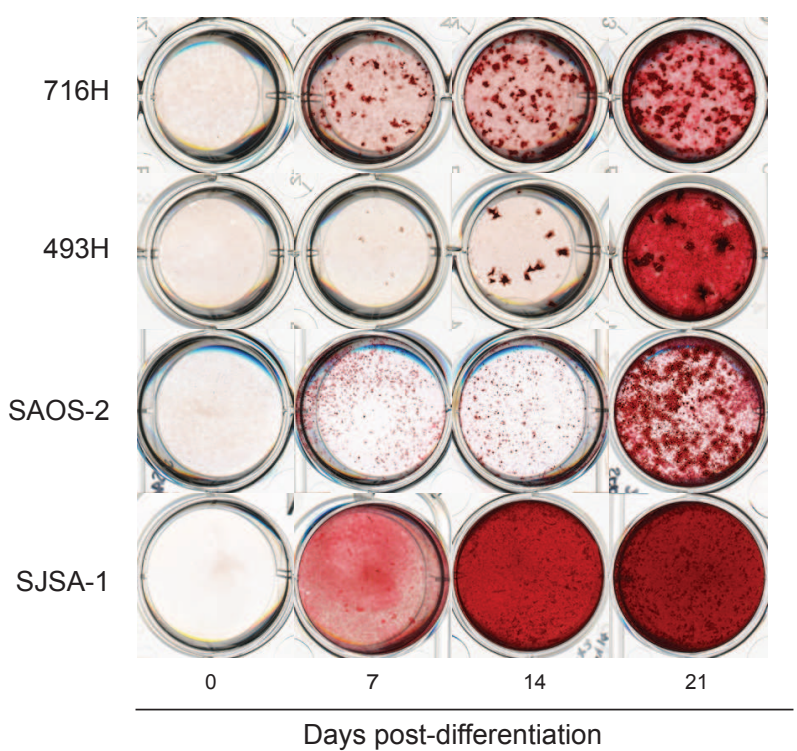

E

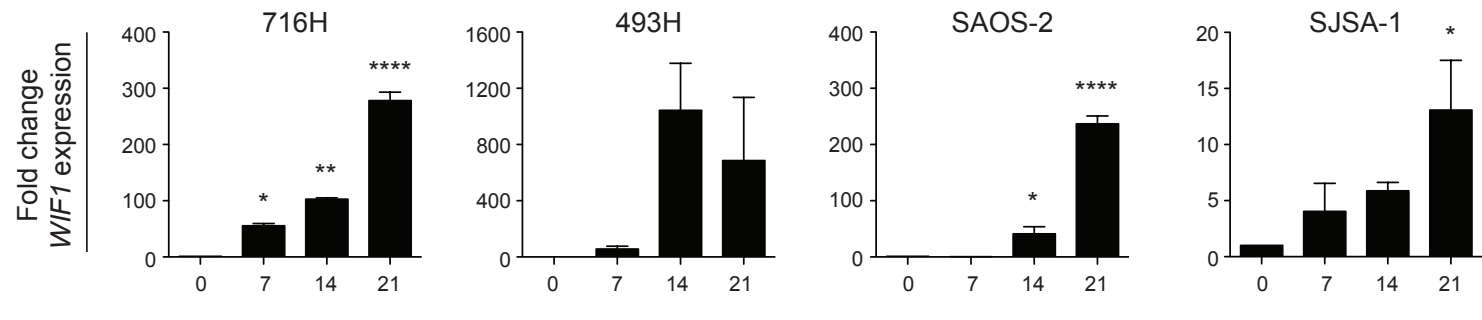

Days post-differentiation
B

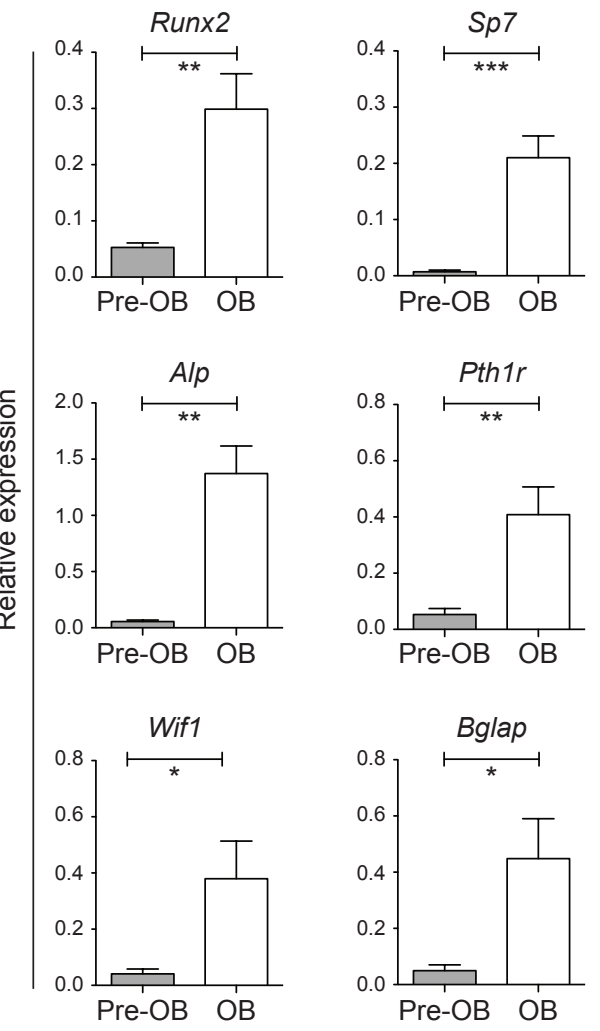

D

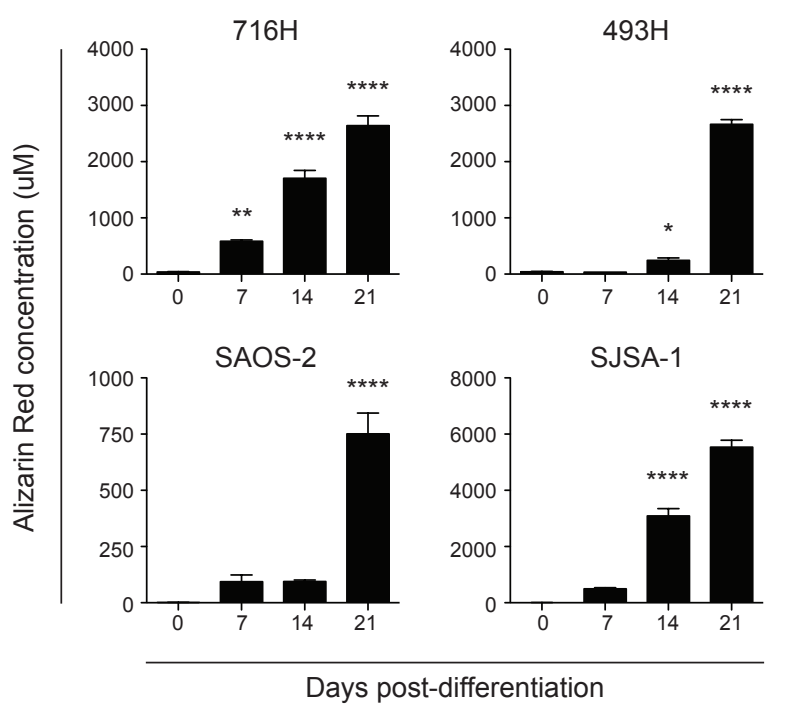

Days post-differentiation 
Supplementary Figure 1:

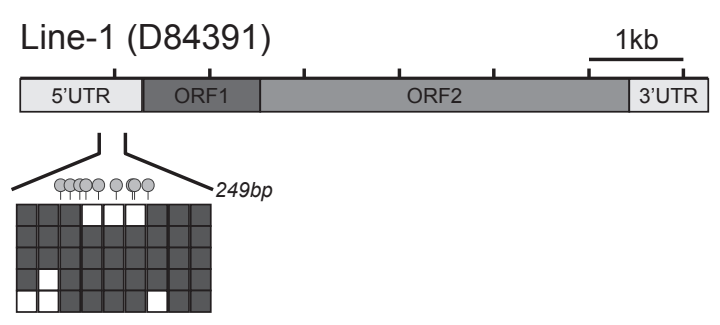


Supplementary Figure 2: The Line-1 repetitive element is hypermethylated in mouse OS. Schematic of the mouse Line-1 repetitive element showing the $249 \mathrm{bp}$ region in the 5'UTR that was analyzed by bisulphite clonal sequencing. The spatial positioning of the nine $\mathrm{CpG}$ dinucleotides assessed in the 249bp region are represented by lollipops. The methylation status of the Line-1 element in $494 \mathrm{H}$ mouse fibroblastic OS cell culture is represented by the colored grid. Each row of boxes represents a single cloned allele. Each box represents a single CpG dinucleotide that is methylated (dark grey) or unmethylated (white). 
Supplementary Figure 2:

A

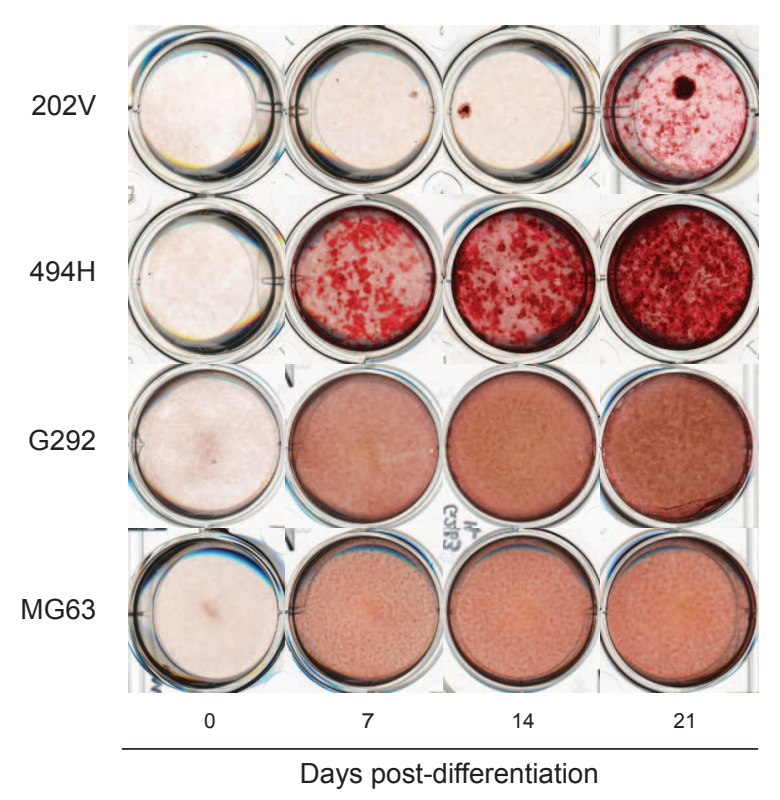

B

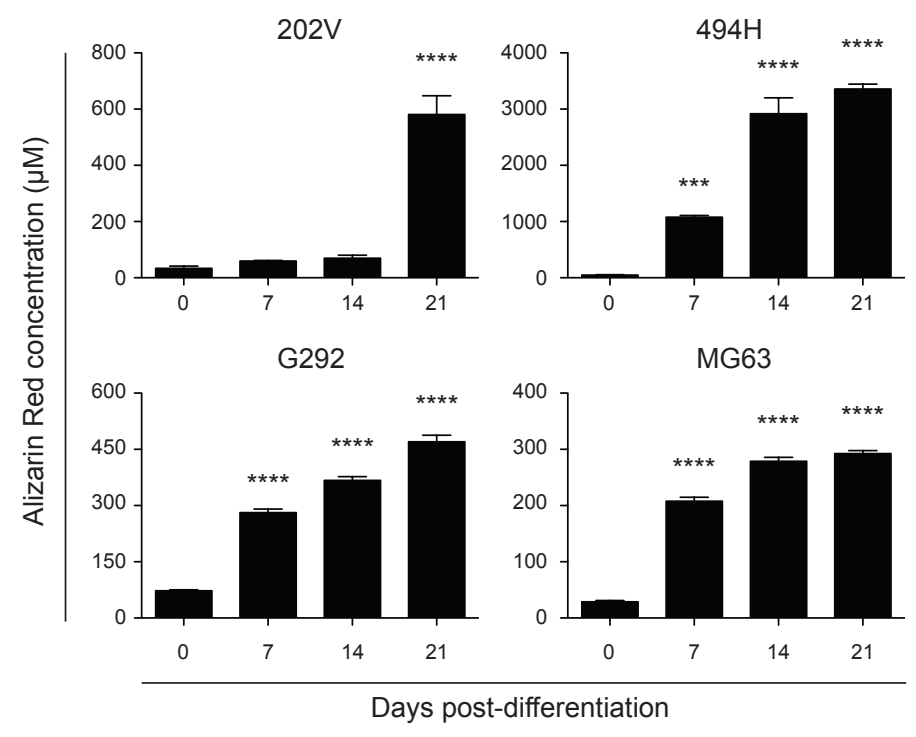

C

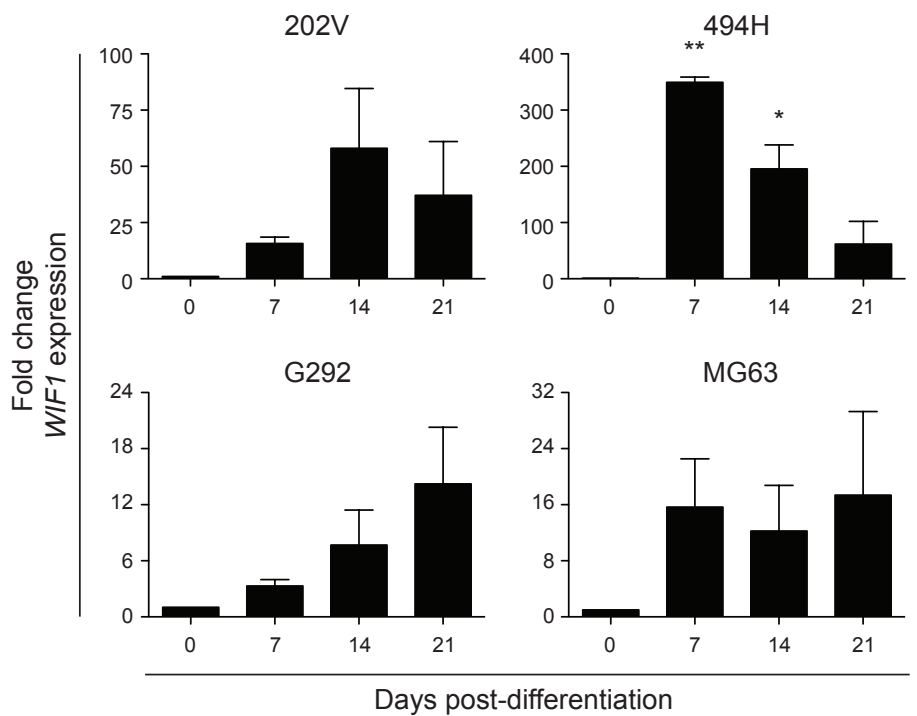


Supplementary Figure 2: WIF1 expression is induced in mouse and human OS cells grown under osteoblastic maturation conditions. (A) Alizarin red staining of mineralized nodules in mouse $(202 \mathrm{~V}$ and $494 \mathrm{H})$ and human (G292, MG63) OS cell cultures grown under osteoblastic conditions over 21 days. (B) Quantitation of mineralization in mouse (202V and $494 \mathrm{H})$ and human OS (G292, MG63) cell cultures over 21 days. Values are mean eluted alizarin red concentration $(\mu \mathrm{M}) \pm \mathrm{SEM}$. Data is from 5 separate assays from an individual experiment and is representative of 2 independent experiments. Asterix denotes statistical significance determined by one-way AVOVA, ${ }^{*} p<0.05,{ }^{* *} p<0.01,{ }^{* * * *} p<0.0001$. (C) Quantitation of Wif1 expression in mouse (202V and 494H) and human OS (G292, MG63) cell cultures grown under osteoblastic conditions over 21 days. Values are mean fold change in Wif1 expression (compared to day 0$) \pm \operatorname{SEM}(n=2-3)$. Asterix denotes statistical significance determined by one-way AVOVA, ${ }^{*} p<0.05,{ }^{* *} p<0.01,{ }^{* * *} p<0.0001$. 


\section{Supplementary Table 1 - Primer Sequences}

\begin{tabular}{|c|c|c|c|c|c|}
\hline Application & Gene / chromatin region & Species & Forward Sequence (5'-3') & Reverse Sequence (5'-3') & Reference \\
\hline Bisulphite Clonal Sequencing & Wif1 F1/R1 & Mouse & TTTTTTAAATTTAATTTTAAGGGGAGTTT & AAACCACTAAAAAAATACAAATACC & Current \\
\hline Bisulphite Clonal Sequencing & Wif1 F2/R2 & Mouse & AATTGGGTTATTAAGAAGATAAATTA & CTAACAAAACTAACAATACCAACAC & Current \\
\hline Bisulphite Clonal Sequencing & Wif1 F3/R3 & Mouse & TTGGTATTGTTAGTTTTGTTAGTAT & ТСТССТСАААТААСТАСССТАСАТС & Current \\
\hline ChIP assays & Wif1 Region 1 & Mouse & AGCAACCCCCGAGGATTCTGGG & GCTCGCTAAGACGACAAGCGC & Current \\
\hline ChIP assays & Wif1 Region 2 & Mouse & TGTCTCTTCGGGCGGCAGGA & TCGCCTGCGCCAGGTGAATG & Current \\
\hline ChIP assays & Wif1 Region 3 & Mouse & CCGCGGTTCCTCCCTCTCGA & GGCAATGCCAGCACGTCCCA & Current \\
\hline ChIP assays & Wif1 Region 4 & Mouse & AGCAGCACAGGTTGGGTCGC & GCGCGAAAGCAGGGAAGGCT & Current \\
\hline ChIP assays & Gapdh & Mouse & CGAAGAACAACGAGGAGAAGATC & CGAACСТСТССССАТTATTGAA & Current \\
\hline Gene Expression & Hprt & Mouse & TGATTAGCGATGATGAACCAG & AGAGGGCCACAATGTGATG & Current \\
\hline Gene Expression & Wif1 & Mouse & AAATGCCCCCAACCCTGCCG & CAGGCTCGCAGACGGGCTTA & Current \\
\hline Gene Expression & Runx2 & Mouse & CTCCGCTGTTATGAAAAACC & TGAAACTCTTGCCTCGTCC & Current \\
\hline Gene Expression & Sp7 & Mouse & TATGCTCCGACCTCCTCAAC & AATAAGATTGGGAAGCAGAAAG & Current \\
\hline Gene Expression & Alp & Mouse & AAACCCAGACACAAGCATTCC & TCCACCAGCAAGAAGAAGCC & Current \\
\hline Gene Expression & Pth1r & Mouse & TTCCAGGGATTTTTTGTTGC & AGTCCAATGCCAGTGTCCAG & Current \\
\hline Gene Expression & Bglap & Mouse & TCTCTCTGACCTCACAGATCCC & TACCTTATTGCССТCCTGCTTG & Current \\
\hline Gene Expression & HPRT1 & Human & TGATTAGCGATGATGAACCAG & AGAGGGCCACAATGTGATG & Current \\
\hline Gene Expression & WIF1 & Human & TGAATTTTACCTGGCAAGCTG & GGACATTGACGGTTGGATCT & Kansara et al (2009) JCl, 119(4):837-51 \\
\hline
\end{tabular}

